\title{
REKONSTRUKTORZY PROFESJONALNI CZY HOBBYSTYCZNI? ROLA I ZNACZENIE STROJU W ŚWIECIE REKONSTRUKCJI HISTORYCZNEJ EPOKI ŚREDNIOWIECZA
}

\begin{abstract}
Abstrakt. Stopień poprawności historycznej odtwarzanych przez rekonstruktorów strojów staje się obecnie jednym z czynników różnicujących odtwórców historycznych. Artykuł stanowi próbę analizy dwóch skrajnych podejść kobiet i mężczyzn do kwestii projektowania własnego ubioru: podejścia profesjonalnego, charakteryzującego się dbałością o historyczną poprawność ubioru oraz podejścia hobbystycznego, przejawiającego się w braku staranności i nie przywiązywaniu wagi do wyglądu stroju. Artykuł będzie ponadto próbą określenia znaczenia ubioru, jego elementów oraz wiedzy na jego temat dla budowania własnej pozycji, autorytetu oraz władzy w świecie rekonstrukcji historycznej epoki późnego średniowiecza.
\end{abstract}

Slowa kluczowe: kreowanie wizerunku, odtwórstwo historyczne, rekonstrukcja historyczna, ubiór.

\section{Wstęp}

Zaprezentowane w artykule zagadnienia stanowią wynik dwóch prowadzonych przeze mnie badań: pierwsze $\mathrm{z}$ nich wykorzystywało teorię światów społecznych, drugie stanowiło analizę stylów życia rekonstruktorów społecznych. Metodą badawczą zastosowaną w pierwszym badaniu była obserwacja uczestnicząca (przeprowadzone zostały także dwa wywiady pogłębione z ekspertami), $\mathrm{w}$ ramach drugiego badania przeprowadzonych zostało czternaście wywiadów swobodnych z rekonstruktorami historycznymi, które dostarczyły bogatego materiału do niniejszego artykułu. Ze względu na specyfikę omawianych kwestii zdecydowałam się na analizę ubioru kobiecego i męskiego w perspektywie światów społecznych, rozwijanej przede wszystkim na gruncie prac Alfreda Schütz'a.

* Mgr, Zakład Socjologii Płci i Ruchów Społecznych, Instytut Socjologii, Wydział Ekonomiczno-Socjologiczny, Uniwersytet Łódzki, ul. Rewolucji 1905 r. nr 41/43, 90-214 Łódź; e-mail: malwina.pietrzyk@gmail.com. 
Jednym z istotniejszych, o ile nie najważniejszym, pojęciem konstruującym teorię świata społecznego jest tzw. „działanie znaczące”, wokół którego skoncentrowane są inne działania uczestników, często poboczne lub drugoplanowe. Różnica między tym działaniem a zwykłym zachowaniem polega, według badaczy, na tym, że jednostka nadaje swojej aktywności znaczenie, a więc postępuje w określony sposób dla uzyskania jakiś celów i zrealizowania interesów. Celowość działania jest także, jak wykażę w dalszej części artykułu, istotnym elementem wyznaczania granic świata rekonstrukcji historycznej. Jednym z podstawowych działań podejmowanych przez omawianą grupę jest prezentacja, a także wykonywanie historycznego ubioru: działania znaczące oraz stroje są więc nierozerwalnie ze sobą powiązane. Analiza ubioru w perspektywie działania znaczącego dotyczy więc nie tylko opisu repertuaru działań (sposobu ubierania się), lecz także identyfikacji sieci znaczeń, nadawanych ubiorowi przez uczestników rekonstrukcji historycznej oraz funkcji, jaką dla nich pełni. Ubiór powinien więc być traktowany (nie tylko w tej analizie) jako rezultat działań jednostki, opatrzony indywidualnymi preferencjami. Przejawem indywidualizacji stroju może być nie tylko jego charakterystyczny bądź oryginalny wygląd, lecz także dostosowanie go do potrzeb własnych lub możliwości finansowych i technologicznych. Jest to szczególnie widoczne w przypadku omawianych w artykule dwóch skrajnych podgrup, należących do świata rekonstrukcji historycznej. Ubiór stanowi także jeden z czynników niezbędnych w procesie identyfikacji jego członków. Dotyczy to zarówno definiowania przynależności do grupy przez samych jej uczestników, jak i określania przynależności danej osoby przez zewnętrznych obserwatorów, nie należących do omawianego świata społecznego. O wiele istotniejsza jest jednak funkcja ubioru dla rekonstruktorów historycznych. Poprawnie historyczny strój, sposób jego wykonania i dbałość o szczegóły stają się bowiem dla rekonstruktorów jednym z kryteriów akceptacji. Przynależność do świata społecznego (a także jej świadomość) jest bowiem jedną z ważniejszych potrzeb. Jedną z możliwości jej spełnienia jest realizacja określonych wzorów, wypracowanych i wyznawanych przez grupę. Owa świadomość wspólnotowości, wpisywania się w ramy społecznego świata oraz jego zasad może prowadzić do integracji jej uczestników i tworzenia się silnych więzi, ale może być także narzędziem budowania pozycji i władzy. Z drugiej jednak strony nieprzestrzeganie ustanowionych nieformalnie zasad, dotyczących ubioru historycznego może prowadzić nawet do wykluczenia danej jednostki ze świata rekonstrukcji historycznej.

Istotne jest także wyjaśnienie używanej przeze mnie terminologii. Z punktu widzenia niniejszej pracy celowo zrezygnowałam z terminu „kostium” na rzecz „ubioru i stroju”. Jak wykazuje Grażyna Bokszańska, etymologia słowa „kostium" sugeruje przebranie, a więc rodzaj stroju zakładanego podczas odgrywania pewnych scen i przedstawień. Słowo „kostium” dotyczy więc prawie wyłącznie sytuacji teatralnych, stanowiąc tym samym element maskarady (B ok s zań ska 2004), sugeruje także, że wraz z kostiumem aktor zmienia swoją tożsamość lub 
też wciela się w jakąś konkretną rolę. W świecie rekonstrukcji historycznej nie mamy, rzecz jasna, do czynienia z maskaradą, ani, wbrew pozorom, przejmowaniem innej tożsamości. Zasadne wydaje się więc użycie pojęć „ubiór” oraz „strój”, tym bardziej, że kojarzone są z immanentnym elementem określonego stylu życia.

\section{Rekonstrukcja historyczna - propozycja definicji}

Nieliczni badacze zajmujący się problematyką rekonstrukcji historycznej proponują podobną jej definicję: rekonstrukcja historyczna jest „,zbiorem działań polegających na wizualnej prezentacji różnego rodzaju dziedzin życia człowieka w przeszłości [...] przez osoby przebrane w stroje i posługujące się przedmiotami [...] wybranej epoki, będące świadomymi odtwórcami” (B o g a ck i 2010). Rekonstrukcja historyczna dąży nie tylko do odtwarzania przedmiotów, będących replikami historycznych znalezisk, lecz także do odtwarzania dawnych obyczajów, obrzędów czy też ogólnie - różnych aspektów życia społecznego i kulturowego ludzi żyjących w dawnych czasach. Najistotniejszym z punktu widzenia niniejszego artykułu pojęciem, pojawiającym się także w definicji, jest tzw. ,świadoma rekonstrukcja”. Najogólniej owa świadomość dotyczy przede wszystkim znajomości źródeł oraz przekazów historycznych, ikonografii oraz tekstów i przekładów dotyczących określonej epoki. Świadomy rekonstruktor jest więc osobą oczytaną, posiadającą niejednokrotnie wykształcenie kierunkowe (np. archeologiczne lub historyczne). Kompleksowa wiedza na temat określonej epoki pozwala rekonstruktorom na wierne odtwarzanie ich kultury materialnej i niematerialnej. Z pojęciem świadomej rekonstrukcji wiążą się przede wszystkim dwa inne, równie istotne problemy: jest to, po pierwsze, zakres pojęciowy terminów „rekonstrukcja historyczna” oraz „odtwórstwo historyczne”, po drugie - co zostanie opisane w dalszej części artykułu - różnice między rekonstruktorami-profesjonalistami a rekonstruktorami-hobbystami.

Wspomniane wcześniej problemy definicyjne dotyczą przede wszystkim traktowanych synonimicznie pojęć „rekonstrukcja historyczna” i „odtwórstwo historyczne", na co zwraca uwagę także Michał B og a cki (2010). Biorąc pod uwagę złożoność świata rekonstrukcji historycznej, jego wewnętrzne podziały oraz nierówności występujące w jego obrębie, należy, nie tylko dla potrzeb tego artykułu, lecz także dla całościowego zrozumienia wieloaspektowości tego problemu, uporządkować znaczenia tych dwóch pojęć.

Termin „rekonstrukcja historyczna” pojawił się najprawdopodobniej na przestrzeni ostatnich dwudziestu lat; za jego rozpowszechnienie odpowiedzialne są w dużej mierze osoby zajmujące się rekonstrukcją dwudziestowieczną, w szczególności zaś militarną epoki I i II wojny światowej. Samo pojęcie „rekonstrukcja" podświadomie, intuicyjnie może się kojarzyć z procesem wytwarzania (dzięki współcześnie dostępnym materiałom i technologiom) replik zachowanych 
obiektów kultury minionych epok, przy czym słowo replika jest tutaj pojęciem kluczowym. Zgodnie z definicją, zawartą w Stowniku języka polskiego PWN, rekonstrukcja oznacza „odtworzenie czegoś na podstawie zachowanych fragmentów, szczątków lub przekazów" (Słownik... 2015). W przypadku omawianego problemu „rekonstruować” oznacza więc wiernie odtwarzać określone przedmioty. Abstrahując od słownikowego znaczenia, termin „rekonstrukcja” kojarzyć się może ponadto z naukami historycznymi, w szczególności zaś archeologią. W kontekście przytoczonej argumentacji, rekonstrukcja historyczna powinna być terminem odnoszącym się jedynie do tych aktywności, które prowadzą do wizualnie jak najwierniejszego odtworzenia konkretnych przedmiotów, będących wytworem określonej kultury minionych czasów (np. średniowiecza). Chociaż wspomniane wcześniej podobieństwo wizualne jest, w świetle przytoczonej definicji, warunkiem wystarczającym dla rekonstrukcji, należy zaznaczyć, że podobienstwo to może dotyczyć aspektów widocznych, a także niemożliwych do zaobserwowania. Poprawna i pełna rekonstrukcja powinna zmierzać do utrzymania wizualnego podobieństwa dzięki wytwarzaniu przedmiotów zgodnie z historycznie potwierdzonymi technikami i metodami oraz przy użyciu materiałów podobnych lub zbliżonych do używanych w dawnych epokach. Rekonstrukcja historyczna jest więc pojęciem dotyczącym kompleksowych aktywności, na które, co zostało wykazanej, składa się szereg czynności koniecznych do zrealizowania.

Zdecydowanie mniej trudności przysparza termin „odtwórstwo historyczne”. „Odtwarzać", nawet w potocznym rozumieniu, oznacza bowiem stworzyć coś na podstawie zachowanych fragmentów. O ile rekonstruowanie oznaczało wierne wytwarzanie przedmiotów na podstawie historycznych znalezisk, o tyle odtwórstwo pozostawia większą swobodę, a nawet daje możliwość twórczej interpretacji, niepopartej naukowymi dowodami. $\mathrm{Z}$ odtwórstwem historycznym będziemy mieć więc do czynienia w sytuacjach, gdy istnieją nieliczne przekazy lub znaleziska historyczne, dotyczące określonego wytworu minionej epoki, lub też są one niewystarczające do pełnej i kompleksowej rekonstrukcji.

Powyższe ustalenia są istotne w przypadku opisu tak złożonego zjawiska, jakim jest rekonstrukcja historyczna. Wprowadzony podział znajduje swoje odzwierciedlenie także w analizowanym przeze mnie świecie rekonstruktorów historycznych epoki średniowiecza. Naturalny podział na uczestników-profesjonalistów oraz uczestników-laików (a więc, w świetle wcześniejszych założeń, uczestników-rekonstruktorów oraz uczestników-odtwórców) jest jednym z najistotniejszych aspektów, różnicujących świat współczesnej rekonstrukcji historycznej. Ze względu na potrzeby tego artykułu, w szczególności zaś dla uniknięcia pojęciowego chaosu i wynikających z niego nieścisłości, zdecydowałam się jednak na przyjęcie terminu „rekonstrukcja historyczna” jako najogólniejszego pojęcia charakteryzującego analizowany przeze mnie świat społeczny. Termin ten będzie więc przeze mnie używany zarówno podczas analizy rekonstrukcji profesjonalnej, jak i hobbystycznej. 


\section{Rekonstruktorzy profesjonalni i hobbystyczni a sposób doboru i komponowania ubioru}

Sposób wykonania i komponowania ubioru jest jednym z najważniejszych elementów rekonstrukcji historycznej, zarówno dla kobiet, jak i dla mężczyzn, strój jest bowiem formą autoprezentacji, wchodzenia w rolę odtwarzanej postaci, przede wszystkim stanowi jednak narzędzie budowania pozycji i autorytetu w świecie rekonstrukcji historycznej, a co najważniejsze - świadczy o wiedzy i doświadczeniu danego rekonstruktora. Ubiór, jego wygląd, a także techniki jego wytwarzania stają się więc najważniejszymi wyznacznikami świadomej rekonstrukcji oraz przynależności do jednej ze skrajnie różnych i nieformalnych grup, jakimi są rekonstruktorzy-profesjonaliści i rekonstruktorzy-hobbyści.

Dla potrzeb tego artykułu zdecydowałam się ograniczyć analizę do dwóch wskazanych grup rekonstruktorów. Należy jednak zaznaczyć, że ten dychotomiczny podział nie wyczerpuje repertuaru nieformalnych grup, działających w obrębie świata rekonstrukcji. Świat rekonstrukcji historycznej, jak większość światów społecznych, jest bowiem dynamiczny i ulega procesowi tzw. segmentacji ( $\mathrm{S}$ tr a u s s 1984). W jego obrębie tworzą się inne subświaty i podgrupy, charakteryzujące się odmiennymi wartościami i wzorcami zachowań. Również określenie granic świata rekonstrukcji historycznej jest dla badaczy zadaniem problematycznym z racji płynności jego granic i braku obiektywnej, wyczerpującej definicji przynależności do niego. Ze względu na powyższe trudności zdecydowałam się więc przyjąć najbezpieczniejszy, a co za tym idzie najbardziej oczywisty podział na rekonstruktorów-profesjonalistów i rekonstruktorów-hobbystów.

Rekonstruktorzy profesjonalni są, w świetle przytoczonej w poprzedniej części artykułu analizy, uczestnikami świadomej rekonstrukcji. W środowisku rekonstrukcji historycznej nazywani są ultrasami. Sama już etymologia tego określenia (od słowa ultra - najwyższy poziom) dostarcza wielu informacji na temat charakterystyki tej grupy. Profesjonaliści starają się rekonstruować każdy element swojego ubioru zgodnie z historycznymi pierwowzorami. Należy zaznaczyć, że elementy takie są nie tylko wizualnie podobne do określonych znalezisk archeologicznych, lecz także są konstruowane przy użyciu średniowiecznych technik (np. tkane na replikach średniowiecznego krosna). Rekonstrukcje strojów profesjonalistów są więc niejednokrotnie replikami średniowiecznych znalezisk, zarówno pod względem wizualnym, jak i konstrukcyjnym. Rekonstruowany strój oraz jego elementy muszą ponadto spełniać trzy wymogi spójności: spójność czasową stroju (każdy jego element pochodzi z określonego czasu historycznego, np. I połowy XV w.), spójność pochodzenia (rekonstruowany ubiór pochodzi z jednego, określonego terenu, np. Rusi, Francji) oraz spójności stylu (wszystkie elementy stroju muszą odpowiadać statusowi odtwarzanej postaci, np. szlachcica, chłopa). Ponadto, w środowisku rekonstruktorów profesjonalnych istnieje zasada dotycząca trzech niezależnych źródeł dotyczących określonego stroju lub 
jego elementu: rekonstruowany ubiór powinien więc być opisany w zachowanych źródłach pisanych (historycznych, np. spisach inwentarza królewskiego lub współczesnych, np. pracach naukowych), znajdować się na obrazie lub w ikonografii średniowiecznej oraz być znaleziskiem archeologicznym. Dopiero ubiór potwierdzony tymi trzema źródłami staje się dla rekonstruktorów autentyczny, tzn. nie pozostawia wątpliwości co do jego wyglądu, wykonania oraz przeznaczenia.

Istotne różnice widoczne są także w obrębie opisywanej grupy i dotyczą przede wszystkim ubioru kobiet i mężczyzn. W przypadku mężczyzn rekonstrukcja stroju obejmuje zarówno odzież codzienną, tzw. cywilną, jak i militarną, a więc różnego rodzaju opancerzenia i elementy zbroi, a także broni. Należy w tym miejscu zaznaczyć, że niewiele kobiet w Polsce zajmuje się rekonstrukcją bitewną; pozostaje to $\mathrm{w}$ dużej mierze domeną mężczyzn, szczególnie w przypadku rekonstruktorów profesjonalnych, dbających o poprawność historyczną i wierne odtwarzanie minionych epok.

Rekonstruktorzy profesjonalni, zajmujący się odtwarzaniem opancerzenia i broni średniowiecznej, muszą dbać o jego historyczną poprawność oraz wytrzymałość i szeroko rozumianą funkcję ochronną. Opancerzenie ma bowiem nie tylko - tak jak w przypadku ubioru kobiet - funkcję estetyczną (która zostanie opisana w dalszej części artykułu), lecz także użytkową, praktyczną, podyktowaną warunkami uczestnictwa w większości masowych imprez o charakterze batalistycznym i inscenizacyjnym. Mężczyźni wykazują więc szeroko rozumianą dbałość o swoje opancerzenie: nadrzędnym działaniem staje się dla nich konserwacja zbroi oraz jej elementów, zapobiegająca pojawieniu się rdzy i wgnieceń, będących pozostałością po odbytych walkach. W tym miejscu należy też wspomnieć o uzbrojeniu paradnym, które jest używane wyłącznie w sytuacjach formalnych. Z racji swojego przeznaczenia nie musi spełniać wymogów bezpieczeństwa, służy bowiem jedynie prezentacji wyposażenia średniowiecznego wojownika.

Podstawową i być może jedyną funkcją stroju profesjonalnych rekonstruktorek jest, jak już wspomniałam wcześniej, funkcja reprezentatywna, pokazowa. Estetyzm strojów oraz ich elementów dla współczesnych obserwatorów może wydawać się jednak wątpliwy - w świece rekonstrukcji historycznej estetyka kobiecego ubioru pojmowana jest jednak inaczej niż dzisiaj. Podstawowe jej kryterium stanowi wspomniana wcześniej poprawność historyczna, osiągana często kosztem współcześnie atrakcyjnego wyglądu. Współcześnie za wzorzec kobiecego stroju uważa się taki, który eksponuje walory właścicielki, przede wszystkim zaś jej kształty i atrybuty (biust oraz biodra). W świetle tych zasad średniowiecznemu damskiemu ubiorowi zdecydowanie bliżej jest do wzorca męskiego stroju: proste i maskujące dekolt kroje sukien, zakrywające włosy chusty, nakrycia głowy przypominające kształtem męskie czapki, a w końcu stonowane i niejaskrawe kolory strojów zdecydowanie nie wpisują się we współczesny kanon kobiecości. Erotyzm i seksualność ubioru kobiet są jednym ze współczesnych kryteriów atrakcyjności; należy jednak zaznaczyć, że w świecie rekonstrukcji historycznej, 
będącej formą odtworzenia kultury minionych czasów, to niewinność i cnotliwość znajdująca wyraz w ubiorze jest najważniejszym kryterium kobiecego piękna.

Damski ubiór (w szczególności jego konkretne elementy) ulega w świetle powyższych rozważań maskulinizacji, z drugiej strony męski strój nabiera cech kobiecych. Mężczyźni zajmujący się rekonstrukcją profesjonalną - w szczególności zaś ci odtwarzający wyższe klasy społeczne - wzbogacają swój strój o elementy, które współcześnie nazwalibyśmy kobiecymi. Feminizację męskiego stroju dostrzec można przede wszystkim na dwóch płaszczyznach. Pierwsza z nich dotyczy fasonu, kroju męskiego ubioru. Tendencją widoczną w świecie rekonstrukcji profesjonalnej jest dążenie do uwydatniania kształtu męskiej sylwetki poprzez obcisłe, przylegające do ciała części ubioru. Jest to szczególnie widoczne w przypadku tzw. nogawic, które współcześnie uznać można za odpowiednik damskich legginsów lub obcisłych spodni. Drugą płaszczyzną są elementy biżuteryjne i ozdobne, będące integralną częścią ubioru. Pierścionki z kamieniami szlachetnymi, ozdobne pasy, brosze, a także (często zdobione haftem i perłami) sakiewki są dopełnieniem męskiego stroju reprezentatywnego. Liczne, typowo kobiece elementy stroju są dla mężczyzn zajmujących się rekonstrukcją profesjonalną nieodzownym elementem kreacji i stanowią jej integralną całość. Świadoma rezygnacja z nich byłaby więc dla przedstawicieli tej grupy rażącym błędem.

Zdecydowanie odmienne zasady komponowania stroju widoczne są w obrębie drugiej analizowanej grupy, czyli rekonstruktorów hobbystycznych. Jej przedstawiciele uważani są za grupę z pogranicza dwóch światów: rekonstrukcji historycznej i świata fantasy. W świecie rekonstrukcji historycznej często określani są w sposób pejoratywny odrzutkami lub mrokami. W przeciwieństwie do rekonstruktorów profesjonalnych, nie wykazują dbałości o poprawność i spójność stroju (dotyczy to zarówno kobiet, jak i mężczyzn). W przypadku rekonstruktorów profesjonalnych rekonstrukcja strojów oznaczała zarówno dbałość o spójność historyczną, jak i techniki wytwarzania. Rekonstruktorzy hobbystyczni komponują swój strój w sposób przypadkowy. Rekonstrukcje takie są jedynie dowolną interpretacją znanych nam przekazów historycznych: elementy strojów, zarówno kobiet, jak i mężczyzn, są więc tworzone w sposób intuicyjny, podstawą stają się domysły i przypuszczenia, nie zaś rzetelna wiedza, wynikająca z badań własnych i doświadczenia. Rdzeniem działalności rekonstruktorów profesjonalnych, priorytetem, którym się kierują jest poprawne komponowanie stroju, zaś rekonstruktorzy hobbystyczni ukierunkowani są na rekreacyjny aspekt rekonstrukcji historycznej, traktują więc ubiór historyczny jako narzędzie pozwalające im uczestniczyć w wydarzeniach o charakterze historycznym.

W przeciwieństwie do rekonstruktorek profesjonalnych, kobiety zajmujące się rekonstrukcją hobbystyczną zwracają uwagę przede wszystkim na atrakcyjność (we współczesnym rozumieniu) swojego stroju, a co za tym idzie wyglądu: często rezygnują one świadomie z poprawnych historycznie elementów ubioru, zastępując je innymi, współczesnymi rozwiązaniami, które w ich mniemaniu 
służą uatrakcyjnianiu wyglądu (dobrym przykładem jest używanie makijażu lub współczesnej biżuterii). Uwspółcześnianie historycznego ubioru jest także podyktowane wygodą - stąd pojawiające się w ubiorze kobiet elementy, będące relatywnie nowoczesnymi rozwiązaniami (gumki do włosów, spinki, współczesna bielizna). Najistotniejszą jednak zasadą, konstruującą sposób doboru i kompozycji ubioru jest zachowanie czy też podtrzymanie atrakcyjnego wyglądu poprzez eksponowanie kobiecych atrybutów. Po pierwsze, dotyczy to często nieprzestrzeganego wśród hobbystek obowiązku zakrywania włosów, noszenia kapeluszy lub płóciennych chust, po drugie - nadmiernego eksponowania biustu oraz sylwetki poprzez zmianę kroju i fasonu noszonych sukien. Uatrakcyjnianie wyglądu ma w tym przypadku wymiar celowy: należy jednak zaznaczyć, że niektóre błędy popełniane przez rekonstruktorki hobbystyczne mogą być popełniane nieświadomie lub są podyktowane innymi niezależnymi czynnikami. Wspomniana wcześniej nieświadomość wynika przede wszystkim z braku wiedzy historycznej lub niewystarczającego jej poziomu. Istotne są również czynniki ekonomiczne, nakłady finansowe, jakimi dysponuje osoba zajmująca się rekonstrukcją historyczną - korzystanie ze współczesnych rozwiązań jest w większości przypadków zdecydowanie tańsze niż zaopatrzenie się w historycznie poprawne elementy ubioru. W końcu umiejętności i zdolności rekonstruktorek stanowią istotny aspekt komponowania ubiorów: ręczne, a nawet maszynowe szycie ustrojów oraz ich elementów wymaga dużego nakładu czasu i zdolności manualnych, a także znajomości technik krawieckich.

Mężczyźni zajmujący się rekonstrukcją średniowiecznego opancerzenia $\mathrm{i}$ broni rezygnują natomiast $\mathrm{z}$ poprawności historycznej, a nawet estetyki na rzecz zwiększenia bezpieczeństwa i funkcji ochronnych, stanowiących podstawową funkcję tych elementów. Stawiają na wytrzymałość, którą osiągają, stosując często współczesne elementy i materiały.

Należy jednak zaznaczyć, że w grupie rekonstruktorów hobbystycznych dostrzec można przynajmniej trzy przeciwstawne tendencje. Pierwszą z nich są niespójne historycznie, niepoprawnie skomponowane, ale zadbane elementy opancerzenia. Drugą stanowi potwierdzone historycznie opancerzenie (a więc takie, które spełnia wymogi świadomej rekonstrukcji), które nie ma estetycznego wyglądu (jest zardzewiałe, posiada liczne uszkodzenia). Trzecią, być może najgorszą, tendencją jest zarówno niehistoryczny, jak i nieestetyczny, zaniedbany ubiór. O ile pierwsza tendencja może wynikać z często nieuświadomionej niewiedzy i braku przygotowania merytorycznego, niezbędnego do uczestnictwa w rekonstrukcji historycznej, o tyle dwie pozostałe są skutkiem świadomych uchybień oraz braku dbałości o wygląd. Zaproponowany podział, jak wynika z moich obserwacji, dotyczy prawie wyłącznie ubioru mężczyzn; kobiety zajmujące się rekonstrukcją historyczną wykazują (często nadmierną) dbałość o schludność i estetyczny wygląd swoich strojów, przy jednoczesnym komponowaniu go w sposób niespójny i niepoprawny historycznie. 


\section{Historyczny ubiór jako świadectwo wiedzy i doświadczenia}

Sposób doboru i komponowania stroju jest oczywiście nierozerwalnie powiązany z wiedzą i doświadczeniem: rekonstruktorzy hobbystyczni to w większości osoby dysponujące jedynie podstawową wiedzą historyczną. Komponowanie ubioru ma więc charakter powierzchowny, ogranicza się jedynie do zachowania podstawowych, bazowych elementów historycznego stroju, przy jednoczesnym braku dbałości o szczegóły. Należy także zaznaczyć, że rekonstruktorzy hobbystyczni to w większości osoby młode lub też uczestniczące w rekonstrukcjach krócej niż rekonstruktorzy profesjonalni. Istotne jest natomiast zrozumienie motywów działania rekonstruktorów hobbystycznych, są to bowiem osoby zarówno nieświadome popełnianych przez siebie błędów w zakresie komponowania stroju, jak i rekonstruktorzy ich świadomi, jednak nie podejmujący żadnych działań naprawczych. Szczególnie widoczne jest to w przypadku kobiet - jak wykazały moje badania, mają one świadomość popełnianych błędów, jednak dzięki niepoprawnym, współczesnym rozwiązaniom zyskują, w swojej opinii, atrakcyjniejszy wygląd, który jest dla nich istotniejszy od wspomnianej wcześniej poprawności historycznej.

Dla rekonstruktorów profesjonalnych podstawowym i najważniejszym celem jest możliwie jak najdokładniejsze odtworzenie strojów z dawnych epok i właśnie to stanowi rdzeń ich działalności. Aspekt wizualny rekonstruowanych strojów jest równie ważny jak niemożliwe do bezpośredniego zaobserwowania sposób i techniki ich wytwarzania. Elementem niezbędnym do takiego poprawnego i świadomego rekonstruowania strojów jest wiedza historyczna: rekonstruktorzy profesjonalni to $\mathrm{w}$ większości osoby zajmujące się rekonstrukcją od co najmniej dziesięciu lat lub osoby o wykształceniu kierunkowym (historycznym lub rzemieślniczym).

Interesującym aspektem są także rzemiosła, którymi zajmują się profesjonaliści. Kobiety reprezentujące grupę rekonstruktorów profesjonalnych trudnią się $\mathrm{w}$ większości krawiectwem, tkactwem i hafciarstwem, a więc profesjami, które w średniowieczu realizowane były również prawie wyłącznie przez kobiety. Relatywnie najmniej kobiet zajmuje się kowalstwem lub wytwarzaniem opancerzenia i broni średniowiecznej - te czynności wykonywane są prawie zawsze przez mężczyzn. Należy jednak zaznaczyć, że zarówno kobiety, jak i mężczyźni, zajmujący się rekonstrukcją profesjonalną, mogą być uznawani w środowisku rekonstrukcji historycznej za autorytety oraz wzory do naśladowania. Poprawne historycznie techniki wykonywania ubiorów stają się więc dla kobiet swoistą przepustką do zdominowanego przez mężczyzn świata rekonstrukcji historycznej. 


\section{Rola i znaczenie ubioru}

Dotychczasowe rozważania na temat kobiecego i męskiego ubioru dotyczyły przede wszystkim jego charakterystyki. $Z$ punktu widzenia przytoczonej w artykule koncepcji działań społecznych istotne jest także przeanalizowanie funkcji ubioru, a także jego symbolicznego znaczenia. Najogólniej funkcje ubioru można podzielić na dwie główne kategorie: rolę w budowaniu pozycji w świecie rekonstrukcji historycznej oraz rolę w definiowaniu przynależności do opisywanego świata spolecznego.

Strój i jego elementy są jednym z ważniejszych wyznaczników pozycji zajmowanych w świecie rekonstrukcji historycznej: ubiór jest formą autoprezentacji, świadczącej o statusie materialnym, przede wszystkim stanowi jednak wyraz i świadectwo stopnia wyspecjalizowania i profesjonalizmu danej osoby. Z tym zagadnieniem wiążą się dwa problemy, wymagające wyraźnego zaakcentowania. Po pierwsze, $\mathrm{w}$ świetle teorii o społecznym wymiarze ubioru realizowanie określonych ról wiąże się z wymogiem dostosowania lub wypracowania odpowiedniego ubioru. Po drugie zaś, określony typ ubioru (a także sposób jego wykonania) będzie skutkował albo awansem w hierarchii świata rekonstrukcji historycznej, albo degradacją, a nawet wykluczeniem z niego. Innymi słowy, ubiór staje się jednym z ważniejszych czynników wpływających na pozycję społeczną zarówno kobiet, jak i mężczyzn, zajmujących się rekonstrukcją historyczną, jest więc nie tylko pewną formą wymogu, uprawniającego do uczestnictwa w rekonstrukcjach (a więc stanowi wyznacznik granic świata), lecz także narzędziem budowania autorytetu i władzy.

Po pierwsze, poprawny historycznie ubiór (jego wygląd i wykonanie) jest podstawową płaszczyzną oceny umiejętności i doświadczenia rekonstruktora. $\mathrm{Na}$ tej podstawie inni uczestnicy definiują rolę, jaką pełni dana osoba w świecie społecznym. Oczywiście repertuar ról nie ogranicza się wyłącznie do zaproponowanego w niniejszym artykule dychotomicznego podziału na dwie skrajne grupy profesjonalistów i hobbystów. Nie każdy profesjonalista uzyskuje bowiem status autorytetu, podobnie nie każdy hobbysta doznaje ostracyzmu i zostaje wykluczony $\mathrm{z}$ analizowanego świata. Zdobywanie autorytetu i władzy jest procesem wymagającym czasu i jest wypadkową wielu czynników. Pierwszym czynnikiem sprzyjającym, umożliwiającym uzyskanie wysokiej pozycji jest oczywiście historycznie poprawny strój oraz, ogólniej mówiąc, wygląd. Drugim jest świadomość dawnych technik i metod wytwarzania konkretnych elementów ubioru, a co za tym idzie specjalizacja w określonej dziedzinie rzemiosła (np. krawiectwo, szewstwo, hafciarstwo). Trzecim, być może najtrudniejszym do zrealizowania, jest prezentacja swoich umiejętności, co prowadzi do rozpoznawalności danego rekonstruktora. Wobec powyższych ustaleń oczywiste staje się stwierdzenie, że największym autorytetem cieszą się osoby doświadczone, zajmujące się rekonstrukcją historyczną od kilkunastu lat. Jak wynika z moich obserwacji w większości są to osoby 
zajmujące się rzemiosłem profesjonalnie, a więc posiadające kwalifikacje i wykształcenie kierunkowe, co jest szczególnie widoczne w przypadku kobiet zajmujących się zawodowo krawiectwem. Ich strój daje świadectwo kunsztu i fachowości, stanowiąc tym samym ,żywą reklamę” ich wyrobów. Wąska grupa, uważana w świecie rekonstruktorów historycznych za profesjonalnych (w szczególności zaś kobiety), może także kreować nowe trendy (a raczej wyznaczać kierunek rekonstrukcjom strojów), które starają się naśladować inni rekonstruktorzy, w tym także hobbystyczni, co także stanowi jeden z wyznaczników wysokiej pozycji zajmowanej w świecie rekonstrukcji historycznej.

Budowanie pozycji w omawianym świecie społecznym może nie ograniczać się wyłącznie do specjalizacji w określonym rzemiośle, choć jest to zdecydowanie najczęstszym zjawiskiem. Rekonstruktorzy profesjonalni mogą bowiem osiągnąć wysoką pozycję jedynie dzięki swojej wiedzy na temat ubioru i technik produkcji. Najważniejszym aspektem staje się więc znajomość różnego rodzaju źródeł historycznych, a także, co wymaga zdecydowanie większego nakładu pracy, działalność badawcza, w szczególności zaś publikacje naukowe dotyczące wybranego zagadnienia. Największym autorytetem cieszą się oczywiście pracownicy naukowi lub osoby zatrudnione w instytutach archeologicznych lub muzeach. Także w tym przypadku istotnym aspektem staje się prezentacja dorobku badawczego oraz wiedzy na forum publicznym, oznaczająca nie tylko dyskusję w wirtualnym świecie (na forach tematycznych i portalach społecznościowych), lecz także fizyczny udział w wydarzeniach o charakterze historycznym.

Istotnym aspektem przy rozważaniach dotyczących roli ubioru w budowaniu pozycji jest odejście od współczesnego rozumienia profesjonalnego stroju lub uniformu, świadczącego o wysokiej pozycji społecznej. Rekonstruktorzy profesjonalni często bowiem odtwarzają stroje niższych klas społecznych (np. ubogich chłopek) i nie wpływa to na ich pozycję w świecie rekonstrukcji historycznej. Podstawowym elementem, służącym budowaniu autorytetu i władzy, zarówno przez kobiety, jak i przez mężczyzn, jest bowiem nie odtwarzanie bogatych klas społecznych, ale wspomniana wcześniej poprawność historyczna strojów, wynikająca z wiedzy i doświadczenia rekonstruktorów. Staje się to szczególnie istotne w przypadku kobiet zajmujących się rekonstrukcją historyczną - strój i wiedza na jego temat daje im możliwość uzyskania wysokiej pozycji w świecie rekonstrukcji historycznej, która zdominowana jest przez mężczyzn oraz ich specjalizacje. Należy tutaj zaznaczyć, że większość kobiet nie bierze bezpośredniego udziału w pokazach o charakterze batalistycznym: ich rola ograniczona jest jedynie do pomagania mężczyznom w czasie i po walkach. Wiedza na temat strojów średniowiecznych, a także ubiór i warsztat rzemieślniczy stanowią często jedyną formę autoprezentacji podczas wydarzeń i pokazów o charakterze rekonstrukcji historycznych. Specjalizacja w dziedzinie średniowiecznego krawiectwa, a także hafciarstwa staje się także czynnikiem sprzyjającym rozpoznawalności rekonstruktorów (w szczególności kobiet). Owa rozpoznawalność często wykracza poza granice opisywanego świata społecznego. 
Rekonstruktorzy profesjonalni zyskują uznanie także wśród (prywatnych lub instytucjonalnych) organizatorów wydarzeń i festynów historycznych, a nawet środowiska naukowego. Awans społeczny dotyczy więc często nie tylko świata rekonstrukcji historycznej, lecz także świata współczesnego.

Po drugie ubiór jest, jak zostało wykazane we wcześniejszej części artykułu, elementem definiującym przynależność do świata rekonstrukcji historycznej. Poprzez realizowanie określonego wzoru (w tym przypadku dotyczącego ubioru) uczestnicy rekonstrukcji historycznej mogą zdobyć uznanie i akceptację innych jej członków, co prowadzi do stworzenia wspólnoty (Leszniewski 2007). Z przynależnością do świata rekonstrukcji wiąże się jeszcze jeden istotny problem. Komponowanie i prezentacja ubioru może mieć bowiem dwojaki charakter: wymiar intencjonalny oraz wymiar intencjonalności wymuszonej (B o k s zań s k a 2004). $\mathrm{Z}$ jednej strony rekonstruktorzy celowo (intencjonalnie) komunikują otoczeniu swoją przynależność do świata rekonstrukcji historycznej poprzez noszenie określonych ubiorów, z drugiej istnieją jednak pewne formalne wymogi, dotyczące ich strojów, niejako wymuszające na uczestnikach stosowny, historyczny ubiór. Strój będzie więc w świecie rekonstrukcji historycznej świadomym wyborem jej uczestników i jednocześnie jednym z wymogów uprawniających do uczestniczenia $\mathrm{w}$ wydarzeniach historycznych.

W szerszym rozumieniu ubiór jest także wyznacznikiem przynależności do określonej grupy rekonstruktorów, a co za tym idzie - stanowi element wyznaczający granice świata rekonstrukcji historycznej. W świetle tych rozważań należałoby przytoczyć koncepcję Alfreda Schütz'a, dotyczącą kryteriów przynależności do określonej grupy, często również nieformalnej (Schütz 2008). Zaproponował on podział na obiektywne znaczenie członkostwa w grupie oraz na subiektywne znaczenie członkostwa w grupie. Pierwszy wyróżniony przez niego typ członkostwa dotyczy aktorów społecznych, pozostających na zewnątrz świata społecznego: przyporządkowują oni członkostwo tym osobom, które posiadają określony repertuar cech charakterystycznych dla ogółu określonej grupy (np. specyficzny ubiór i sposób zachowania). Subiektywne znaczenie członkostwa w grupie nadawane jest przez samych jej uczestników na podstawie subiektywnej oceny oraz indywidualnych poglądów. W szerszym rozumieniu jest więc nierozerwalnie połączone z systemem symbolicznych znaczeń, wymian gestów i zachowań członków grupy. Ubiór rekonstruktorów będzie więc $\mathrm{w}$ świetle przytoczonej koncepcji elementem zarówno subiektywnego i obiektywnego znaczenia członkostwa. Z punktu widzenia tego artykułu, o wiele istotniejsza wydaje się kategoria subiektywnego członkostwa: indywidualna lub grupowa ocena przynależności określonej osoby do świata rekonstrukcji historycznej (wyznaczana na podstawie jakości jego ubioru) jest obecnie jedną z najbardziej kontrowersyjnych (dla samych jej uczestników) kwestii rekonstrukcji historycznej. Technologie wypracowane przez rekonstruktorów historycznych są także jednym z wyznaczników granic omawianego świata: postępująca specjalizacja wytwarzania strojów, połączona z dążeniem do spełnienia wszystkich wymogów poprawności 
historycznej jest najważniejszym kryterium definiowania przynależności do jednej z dwóch grup (profesjonalistów lub hobbystów).

O ile przynależność do świata rekonstrukcji historycznej jest w przypadku rekonstruktorów profesjonalnych bezsprzeczna i nie podlega dyskusji, o tyle sposób komponowania ubioru przez rekonstruktorów hobbystycznych dostarcza pewnych wątpliwości. Rekonstruktorzy hobbystyczni uważani są często za osoby znajdujące się na peryferiach opisywanego świata, a nawet za osoby nieuprawnione do udziału w rekonstrukcjach historycznych. Jest to oczywiście subiektywna ocena, w większości formułowana przez uczestników charakteryzujących się wyższym stopniem profesjonalizmu i dotyczy zarówno kobiet, jak i mężczyzn. Należy w tym miejscu zaznaczyć, że to właśnie rekonstruktorzy profesjonalni czują się niejako zobligowani do wyznaczania granic świata rekonstrukcji historycznej, a także do definiowania subiektywnych kryteriów przynależności do niego. Doskonałym przykładem mogą być grupy założone na portalach społecznościowych, których głównym celem jest komentowanie i dyskutowanie na temat niepoprawnych historycznie strojów noszonych przez kobiety i mężczyzn, zajmujących się rekonstrukcją hobbystyczną. Wspomnieć należy także o zwiększającej się liczbie wymogów formalnych (dotyczących strojów i ich poprawności), których spełnienie uprawnia do uczestnictwa w wydarzeniach i rekonstrukcjach historycznych (przykładem jest tzw. „czerwona książeczka”, zawierająca wymogi, jakie musi spełniać strój osoby, która chce uczestniczyć w corocznych obchodach bitwy pod Grunwaldem). Regulaminy te są tworzone zarówno przez rekonstruktorki profesjonalne (dotyczą one wówczas wymogów stroju kobiecego), jak i rekonstruktorów profesjonalnych (dotyczą wymogów opancerzenia i męskiego stroju cywilnego). Wprowadzanie takich wymogów formalnych daje więc rekonstruktorom profesjonalnym możliwość realnego decydowania o tym, kto jest uprawniony do uczestniczenia w największych wydarzeniach o charakterze historycznym. Rekonstruktorzy hobbystyczni często są więc w sposób formalny bądź nieformalny wykluczani ze świata rekonstrukcji historycznej, uczestniczą wówczas jedynie w wydarzeniach o charakterze komercyjnym bądź rozrywkowym.

Równie interesujący w rozważaniach na temat granic świata rekonstrukcji historycznej jest fakt tworzenia przez rekonstruktorów profesjonalnych zamkniętych podgrup, do których należą osoby o podobnych zainteresowaniach i poziomie specjalizacji w określonej dziedzinie. W Polsce ta dość liczna grupa zrzeszona jest w kilku niezależnych stowarzyszeniach, do których należą zarówno kobiety, jak i mężczyźni. Są to: Projekt 14 (zrzeszający osoby zajmujące się rekonstrukcją XIV- i XV-wieczną) oraz Projekt Volk, do którego należą rekonstruktorzy epoki wczesnego średniowiecza. Rekonstruktorzy profesjonalni często tworzą więc ekskluzywne grupy, zrzeszające osoby o podobnym stopniu specjalizacji, a także biorą udział w wydarzeniach i pokazach historycznych o restrykcyjnych wymogach dotyczących strojów i ich poprawności, w których, rzecz jasna, nie biorą udziału rekonstruktorzy hobbystyczni. 


\section{Zakończenie}

Niniejszy artykuł jest analizą niewielkiego wycinka świata społecznego rekonstrukcji historycznej: nie wyczerpuje on repertuaru złożoności i wieloaspektowości tego zjawiska, które obecnie ulega dynamicznym przemianom. Uchwycenie tych subtelnych zmian wymaga od badacza nie tylko gruntownego przygotowania merytorycznego, lecz także cierpliwości i wnikliwości, co może okazać się zadaniem trudnym i problematycznym, szczególnie dla osób nie dostrzegających motywów działań rekonstruktorów historycznych lub ignorujących je.

Dalszych badań wymaga zdecydowanie zagadnienie indywidualnego znaczenia ubioru w opinii samych rekonstruktorów: wzbogacenie analizy o cytaty i przykłady wypowiedzi urozmaiciłyby teoretyczne rozważania, stanowiłyby także swoiste potwierdzenie zaprezentowanych założeń. Interesującym badawczo polem są także liczne subświaty, funkcjonujące w granicach świata rekonstrukcji historycznej, a co za tym idzie - różnice w zachowaniach i działaniach osób rekonstruujących różne epoki i dzieje (np. średniowiecza i renesansu). Zagadnienia te, z racji swej złożoności, stanowią jednak oddzielny temat szerszej publikacji.

\section{Bibliografia}

B o g a c k i M. (2010), O współczesnym „ożywianiu” przeszłości - charakterystyka odtwórstwa historycznego, „Turystyka Kulturowa”, nr 5, s. 4-24.

B o k s z án ska G. (2004), Ubiór w teatrze życia spolecznego, „Monografie Politechniki Łódzkiej", s. 14-31.

D o w g i ałł o B. (2013), Socjolog w szafie. Prezentacja techniki pomocnej w badaniu ubierania się jako działania, „Przegląd Socjologii Jakościowej”, T. IX, nr 2, s. 49-61.

L e s z n i e w s k i T. (2007), Moda i tożsamość - dylematy wspótczesnego człowieka w świecie konsumpcji, [w:] T. S z l e n d a k, K. P i e trow i c z (red.), Rozkoszna zaraza. O rzadach mody i kulturze konsumpcji, Wydawnictwo Uniwersytetu Wrocławskiego, Wrocław.

Marze c W. (2011), Granice (teorii) społecznych światów, „Przegląd Socjologii Jakościowej”, T. II, nr 1, s. 1-4.

Melosik Z. (2006), Męska obsesja ciatem, [w:] Z. Melosik, Kryzys męskości w kulturze wspótczesnej, Oficyna Wydawnicza Impuls, Kraków., s. 21-23.

P i e tr z y k M. (2013), Style życia rekonstruktorów historycznych epoki średniowiecza, niepublikowana praca magisterska.

P s t r o c k a - R a k M. (2013), Uczestnictwo reanimatorów dawnej historii w imprezach turystyki kulturowej na przykładzie inscenizacji Bitwy pod Grunwaldem, „Turystyka Kulturowa”, nr 4, s. 5-18.

S c h ü t z A. (1984), Potoczna i naukowa interpretacja ludzkiego działania, [w:] E. M o k r z y c k i, Kryzys i schizma. Antyscjentystyczne tendencje $w$ socjologii wspótczesnej, t. 1, Państwowy Instytut Wydawniczy, Warszawa, s. 137-150.

S chütz A. (2008), Równość a struktura znaczeniowa świata spolecznego, [w:] A. S chütz, O wielości światów: szkice z socjologii fenomenologicznej, NOMOS, Kraków, s. 153-188.

S c h ü t z A. (2009), Świat spoleczny i teoria działania społecznego, [w:] P. S z t o m p k a, M. K u c i a (red.), Socjologia. Lektury, ZNAK, Kraków, s. 64-69. 
S i m m e 1 G. (1980), Filozofia mody, [w:] S. M a g a la, Simmel, Wiedza Powszechna, Warszawa, s. $180-212$.

Słownik języka polskiego PWN (2015), wersja online, http://sjp.pwn.pl.

S tr a u s s A. (1984), Social Worlds and Their Segmentation Processes, „Studies in Symbolic Interaction", Vol. 5, ed. N. Denzin, s. 123-139.

Malwina Pietrzyk-Jagielska

\section{PROFESSIONAL OR HOBBY REENACTMENT? ROLE AND MEANING OF CLOTHES IN SOCIAL WORLD OF MEDIEVAL HISTORICAL REENACTMENT}

Summary. Historical incorrectness of reenactor's costumes is one of the main reasons for rejection and exclusion from the social world of historical reenactment. In this article I will try to analyze two extreme women's and men's approaches to designing their own clothing: professional approach, characterized by attention to historical accuracy of clothing, and hobby approach, manifested in lack of diligence and historical awareness. The article will also attempt to determine the significant role of both clothes, it's elements and knowledge in building position and authority in social world of medieval historical reenactment.

Keywords: historical reenactment, living history, historical role-playing, creating the self-image, costumes, clothing. 